\title{
SYNTHESIS, CHARACTERIZATION AND DFT CALCULATIONS OF SCHIFF- BASE VANADIUM(V) COMPLEXES DERIVED FROM SALICYLDEHYDE WITH 1,2-DIAMINOPROPANE OR 2-PICOLYLAMINE
}

\author{
Enas S. Dafallah ${ }^{\mathrm{a}}$, Hassan I. Nimir ${ }^{\mathrm{b}}$, Elmugdad A. Ali ${ }^{\mathrm{a}}$, Mohamed R. Shehata \\ ${ }^{a}$ Department of Chemistry, Faculty of Science, Sudan University of science and technology \\ ${ }^{b}$ Department of Chemistry \& Earth Sciences, Qatar University, \\ P.O. Box 2713, Doha, state of Qatar.hnimir@qu.edu.qa \\ ${ }^{c}$ Department of Chemistry, Faculty of Science, University of Cairo, Giza, Egypt
}

\begin{abstract}
Two ligands were derived from two sciff-bases of salicylaldehyde with 1,2-diaminopropane, Sal-DAP (L1) and salicylsaldehyde with 2-picolyamine, Sal-PA (L2) and their novel dioxovanadium complexes were synthesized. The complexes $\mathrm{C} 1,\left[\mathrm{VO}_{2}(\mathrm{Sal}-\mathrm{DAP})\right]$ and $\mathrm{C} 2,\left[\mathrm{VO}_{2}(\mathrm{Sal}-\mathrm{PA})\right]$ are characterized by conductivity measurements, magnetic susceptibility, UV-Vis, IR, thermal analysis, ${ }^{1} \mathrm{H}$ - and ${ }^{13} \mathrm{C}-\mathrm{NMR}$. The molecular structure of the complexes C1 and C2 were confirmed using the DFT calculation to obtain the optimized geometries using the Gaussian09 program at the B3LYP/LANL2DZ level of theory. The vanadium atoms in the two complexes were coordinated in distorted trigonal bipyramidal geometries with L1 acting as a tridentate ligand through nitrogen atoms and one deprotonated phenol oxygen atom leaving the other phenol group free, and L2 acting as a tridentate ligand through nitrogen atoms and deprotonated phenol oxygen atom.
\end{abstract}

Keywords: Schiffbase, Vanadium(v), DFT Calculations, Salicyldehyde, 1,2-diaminopropane 2picolyamine

\section{INTRODUCTION}

Vanadium complexes play an important role in biological as well as in catalytic processes. In both cases chiral properties implemented by the ligand frame work can be relevant for specific properties of the systems. In general, this leads to the presence of diastereomers generated by the additional chiral center at the vanadium site [1]. Schiff bases derived from aromatic amines and aromatic aldehydes have a wide variety of applications in many fields, e.g., biological, inorganic and analytical chemistry $[2,3]$ and considered to be a very important class of compounds that are widely used due to their good solubility properties and their remarkable versatility [4]. Schiff bases and their metal complexes are known to exhibit a broad variety of biological activity such as anti-viral, [5] anti-parasitic, [6] anti-bacterial, [7] anti-inflammatory, [8] antitumor, [9,10] anti-HIV, [11] anticancer, [12] etc. A large variety of vanadium complexes with ligands bearing oxygen and nitrogen donors have been reported as structural and functional mimics of biological systems [1317].

\section{EXPERIMENTAL}

\subsection{Materials}

1,2-Diaminopropane, 2-Picolyamine, ethanol and Diethyl ether were obtained from Aldrich. Vanadium pentaoxide is obtained from Alfa Aesar. Salicylaldehyde is obtained from Loba Chemie, All reactions were performed in argon atmosphere.

\subsection{Instrumentation}

The melting points of were determined by Fisher-Johns melting point apparatus in ${ }^{\circ} \mathrm{C}$ Fisher Scientific Company - USA model 6200, Molar conductivities of freshly prepared DMF complexes solutions $c=1.0 \times 10^{-3} \mathrm{Mol} / \mathrm{dm}^{-3}$ were measured on conductivity meter modelJENCO-3173R-USA, The magnetic susceptibilities were measured on Sherwood scientific-England, UV/Vis spectra in complexes solutions $\left(c=1.0 \times 10^{-3} \mathrm{~mol} \mathrm{dm}^{-3}\right)$ were recorded on UV.3101PC-Schimadzu Japan, Infrared spectra were recorded on a 
2<smiles>CC(N)CN=Cc1ccccc1O</smiles><smiles>NCc1ccccn1</smiles><smiles></smiles><smiles>Oc1ccccc1/C=N/Cc1ccccn1</smiles>

(L2)

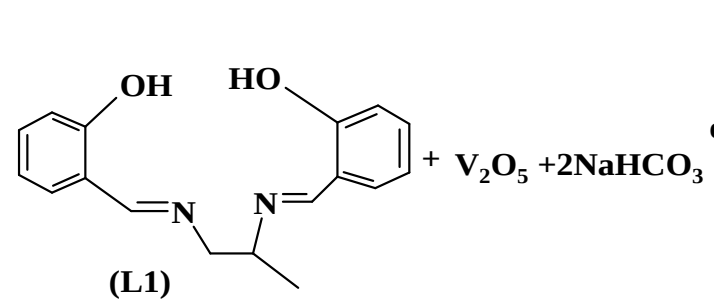

(L1)

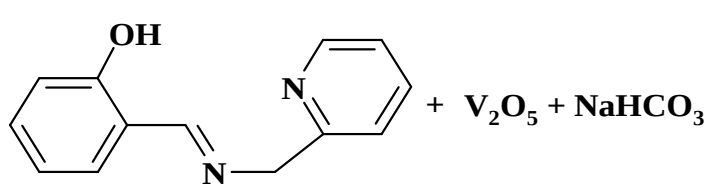

(L2)

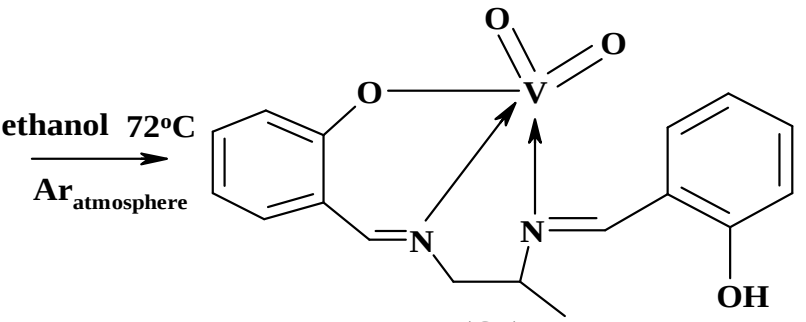

(C1) washed and dried. Data for $\mathrm{C}_{17} \mathrm{H}_{18} \mathrm{~N}_{2} \mathrm{O}_{2}\left(M_{\mathrm{f}}\right.$ 282.34); yield $74 \%$, yellow color; m.p. $140{ }^{\circ} \mathrm{C}$; Anal. Calcd: C, 72.32; H, 6.43; N, 9.92 $\%$. Found: C, 72.4; H, 6.5; N, $9.8 \%$.

\section{Sal-PA}

[ $\mathrm{C}_{13} \mathrm{H}_{12} \mathrm{~N}_{2} \mathrm{O}$ ]

(L2) Schiff base ligand by mixing (2.42 g, $20 \mathrm{mmol}$ ) of

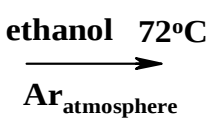<smiles></smiles>

(C2)

Scheme 2: preparation of complexes C1 and C2

8001-PC FT-IR- Schimadzu spectrophotometer using $\mathrm{KBr}$ pellets in the mid-infrared region 4000-400 $\mathrm{Cm}^{-1}$, NMR spectra were recorded on a Varian Mercury VX-300 and VX-500 $\mathrm{MH}_{\mathrm{z}}$ NMR Spectrometer, ${ }^{1} \mathrm{H}$ spectra were run at 75.46 $\mathrm{MHz}$ and ${ }^{13} \mathrm{C}$ spectra were run at $300 \mathrm{MHz}$.in DMSO- $\mathrm{d}_{6}$ as a solvent and TMS as an internal standard. Chemical shifts $(\delta)$ are reported in ppm. TGA was carried on a TGA-Q500 Thermo Gravimetric Analyzer.

\subsection{Synthesis}

\subsubsection{Synthesis of the Schiff bases L1 \& L2}

Sal-DAP $\left[\mathrm{C}_{17} \mathrm{H}_{18} \mathbf{N}_{2} \mathbf{O}_{2}\right]$ (L1) Schiff base ligand was prepared by mixing (2.42 g, 20 mmol)of salicyldehyde with $(0.74 \mathrm{~g}, 10 \mathrm{mmol})$ of 1,2-diaminopropane in $20 \mathrm{~mL}$ ethanol with continuous stirring and reflux for $3.5 \mathrm{~h}$ at $72{ }^{\circ} \mathrm{C}$, Scheme 1. Yellow solid was formed and filterd, salicylaldehyde with (2.16 g, $20 \mathrm{mmol})$ of 2picolyamine in $20 \mathrm{~mL}$ ethanol with continuous stirring and reflux for $3.5 \mathrm{~h}$ at $72{ }^{\circ} \mathrm{C}$, Scheme 1 . Brown oily solid formed and kept in referigerator cooling for two weeks, bright yellow solid was formed, filterd, washed and dried. Data for $\mathrm{C}_{13} \mathrm{H}_{12} \mathrm{~N}_{2} \mathrm{O}\left(M_{\mathrm{f}}=212.25\right)$; Yellow color; m.p. $130^{\circ} \mathrm{C}$; yield (69\%); Anal. Calcd: C, 73.57; $\mathrm{H}$, 5.70, N, 13.20\%. Found: C, 73.4; H, 5.8; N, $13.3 \%$.

\subsubsection{Synthesis of the Schiff base complexes}

Scheme 2 illustrates the synthetic routes and final structures of all synthesized complexes (C1) and (C2).

[VO $\mathbf{V}_{2}$ (Sal-DAP)] (C1) was prepared by (1.81 $\mathrm{g}, 10 \mathrm{mmol}$ ) of vanadium pentaoxide was 
SYNTHESIS, CHARACTERIZATION AND DFT CALCULATIONS ...

dissolved in aquoes solution of sodium bicarbonate (1.68 g, $20 \mathrm{mmol})$ and solutoin was stirred for $15 \mathrm{~min}$, (2.82 g, $10 \mathrm{mmol}$ ) of ligand (L1) was dissolved in $30 \mathrm{ml}$ ethanol and added to the above solution, the mixture was stirred and refluxed under argon atmosphere for $6 \mathrm{~h}$ at $72^{\circ} \mathrm{C}$, Scheme 2. Yellow ppt was formed, filterd off and washed with ethanol. Data for $\mathrm{C}_{17} \mathrm{H}_{17} \mathrm{~N}_{2} \mathrm{O}_{4} \mathrm{~V}\left(M_{\mathrm{f}}=\right.$ 364.27 ); yield $77 \%$, yellow color; m.p. $280^{\circ} \mathrm{C}$; Anal. Calcd: C, 56.05; H, 4.70; N, 7.69 \%. Found: C, 55.8; H, 4.6; N, 7.8\%.

[ $\mathbf{V O}_{2}$ (Sal-PA)] (C2) was prepared by $(1.81 \mathrm{~g}$, $10 \mathrm{mmol}$ ) of vanadium pentaoxide dissolved in aquoes solution of Sodium bicarbonate (1.68 g, $20 \mathrm{mmol}$ ) and solutoin was stirred for $15 \mathrm{~min}$, (2.12 g, $10 \mathrm{mmol}$ ) of ligand (L2) was dissolved in $30 \mathrm{ml}$ ethanol and added to the above solution,the mixture was stirred and refluxed under argon atmosphere for $48 \mathrm{~h}$ at $72^{\circ} \mathrm{C}$, Scheme 2 . Greenwish yellow ppt was formed, filterd off, washed with ethanol and dried. Data for $\mathrm{C}_{13} \mathrm{H}_{11} \mathrm{~N}_{2} \mathrm{O}_{3} \mathrm{~V}\left(M_{\mathrm{f}}=294.18\right)$; yield 51\%; greenish yellow color; m.p. $255^{\circ} \mathrm{C}$; Anal. Calcd: C, 53.08; H, 3.77; N, 9.52; found C, 52.9; H, 3.9; N, 9.6.

\section{RESULTS AND DISCUSSION}

\subsection{Physiochemical data}

The melting points of complexes $\mathrm{C} 1, \mathrm{C} 2$ were found to be $>250^{\circ} \mathrm{C}(\mathrm{C} 1=280$ and $\mathrm{C} 2=$ $255^{\circ} \mathrm{C}$ ). The magnetic moment is calculated from the magnetic susceptibility $d$-configuration $\mathrm{C} 1 d^{0}$ C2 $d^{0}$ and number of unpaired electrons $\mu$ s C1= $0.36-\mu$ s $\mathrm{C} 2=0.26$ for Vanadium $\mathrm{V}^{+5}$ ions with a tigonal bipyramidal geometry. Molar conductivities of freshly prepared DMF complexes C1 and C2 solutions, $c=1.0 \times 10^{-}$ ${ }^{3} \mathrm{Mol} / \mathrm{dm}^{-3}$ were $\mathrm{C} 1=23.05 \mathrm{mScm}^{2} \mathrm{~mol}^{-1}-\mathrm{C} 2=$ $24.3 \mathrm{mScm}^{2} \mathrm{~mol}^{-1}$ which indicates its nonelectrolytic nature, Table 1.

\subsection{Spectroscopic studies}

\subsubsection{UV/Vis Spectra of C1 \& C2}

The electronic spectra of metal complexes were recorded, Figure 1, and show two high energy absorption bands for C1 (208, 262 and very week at $318 \mathrm{~nm})$ and $\mathbf{C 2}$ (210, 259 and week at $322 \mathrm{~nm}$ ).

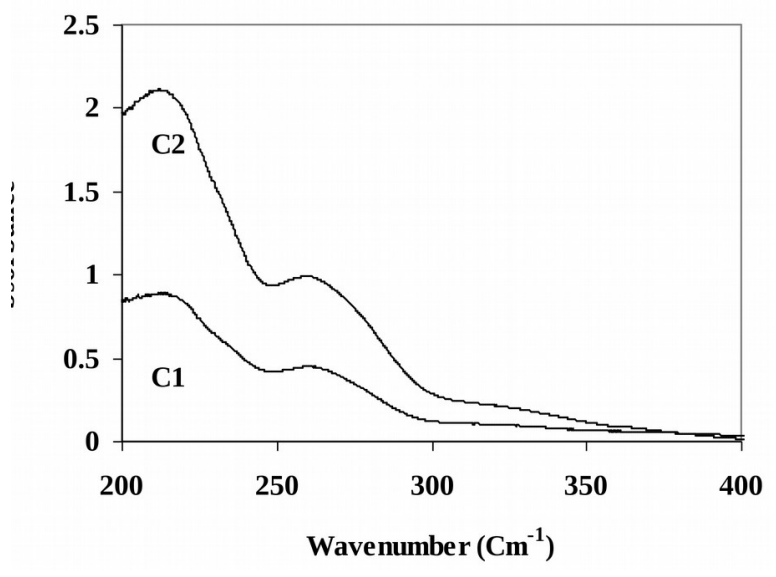

Fig. 1: UV/Vis Absorption spectra of C1 and C2

Table 1: Molar conductance values, magnetic measurement, and UV/Vis-bands of $\mathrm{C} 1$ and C2

\begin{tabular}{|c|c|c|c|}
\hline $\begin{array}{c}\text { Codes } \\
\text { Name of } \\
\text { the } \\
\text { complex }\end{array}$ & $\begin{array}{c}\text { Molar } \\
\text { conductance } \\
\left(\Omega^{-1} \mathrm{~cm}^{-1} \mathrm{~mol}^{-1}\right)\end{array}$ & $\begin{array}{c}\text { Magnetic } \\
\text { values } \\
(298 \mathrm{~K})\end{array}$ & $\begin{array}{c}\text { Bands } \\
\text { observed } \lambda_{\max }\end{array}$ \\
\hline$C 1$ & 23.05 & $\begin{array}{c}\mu \mathrm{s} 0.36 \\
\text { diamagnetic }\end{array}$ & $\begin{array}{c}208,262 \\
\text { and } 318(\mathrm{br})\end{array}$ \\
\hline$C 2$ & 24.3 & $\begin{array}{c}\mu \text { s } 0.26 \\
\text { diamagnetic }\end{array}$ & $\begin{array}{c}210,259 \\
\text { and } 322(\mathrm{br})\end{array}$ \\
\hline
\end{tabular}

\subsubsection{Infrared Spectra of C1 and C2 complexes (IR)}

The IR spectra of complexes (C1 and C2) and their free ligands (L1 and L2) were determined, Figures 2 and 3.

The free ligands L1 and L2 characteristic stretching vibration bands appear at 1635 and $1629 \mathrm{~cm}^{-1}$ corresponding to the $\mathrm{C}=\mathrm{N}$ vibration [18-21], which are shifted to 1629 and 1624 $\mathrm{cm}^{-1}$ in their complexes C1 and C2, respectively indicating coordination of the nitrogen to vanadium [18-21]. The broad vibration bands above $3000 \mathrm{~cm}^{-1}$ characteristic of the stretching frequencies of $\mathrm{H}$-bonding $\mathrm{OH}$ groups. The $(\mathrm{O}-\mathrm{H})$ vibration was present in $\mathrm{C} 1$ which confirms the presence of one of the $\mathrm{OH}$ group uncoordinated in the optimized complex. The absence of $(\mathrm{O}-\mathrm{H})$ vibration in the complex $\mathrm{C} 2$ indicates the coordination of the oxygen after deprotonation of $\mathrm{OH}$ group. The complexes exhibit the characteristic $(\mathrm{V}=\mathrm{O})$ bands at 881 and $921 \mathrm{~cm}^{-1}$ for complex C1 and 
at 844 and $1004 \mathrm{~cm}^{-1}$ for complex C2 [18-21].

The (V-O) bands at 618 and $602 \mathrm{~cm}^{-1}$ and (VN) bands at $541 \mathrm{~cm}^{-1}, 544 \mathrm{~cm}^{-1}$ for complex C1 and C2; respectively [18-21], Figures 2 and 3.

\subsubsection{Nuclear Magnetic Resonance Spectrophotometer (NMR)}

The ${ }^{1} \mathrm{H}$ and ${ }^{13} \mathrm{C}$ NMR data confirm the complex formation and the coordination mode of the Schiff-base ligand.
${ }^{1} \mathrm{HNMR}$ (DMSO- $\mathrm{d}_{6}, \mathrm{ppm}$ ): $\delta=1.18$ and $1.32\left(\mathrm{CH}_{3}\right), 3.05(\mathrm{CH}), 3.36\left(\mathrm{CH}_{2}\right), 6.78-7.55$ (8H aromatic), 8.55 and $8.88(2 \mathrm{H}, \mathrm{H}-\mathrm{C}=\mathrm{N})$ and the presence of one uncoordinated phenolic $\mathrm{OH}$ was confirmed by chemical shift $\delta=13.40$ $(1 \mathrm{H}, \mathrm{H}-\mathrm{O})$, Figures 4.

${ }^{13} \mathrm{CNMR} \quad\left(\right.$ DMSO- $\left.\mathrm{d}_{6}, \quad \mathrm{ppm}\right): \quad \delta=20.70$ $\left(\mathrm{CH}_{3}\right), 65.00(\mathrm{CH}), 65.50\left(\mathrm{CH}_{2}\right), 116.94-163$ (12C, aromatic) $165.70(2 \mathrm{C}, \mathrm{C}=\mathrm{N})$, Figures 4.

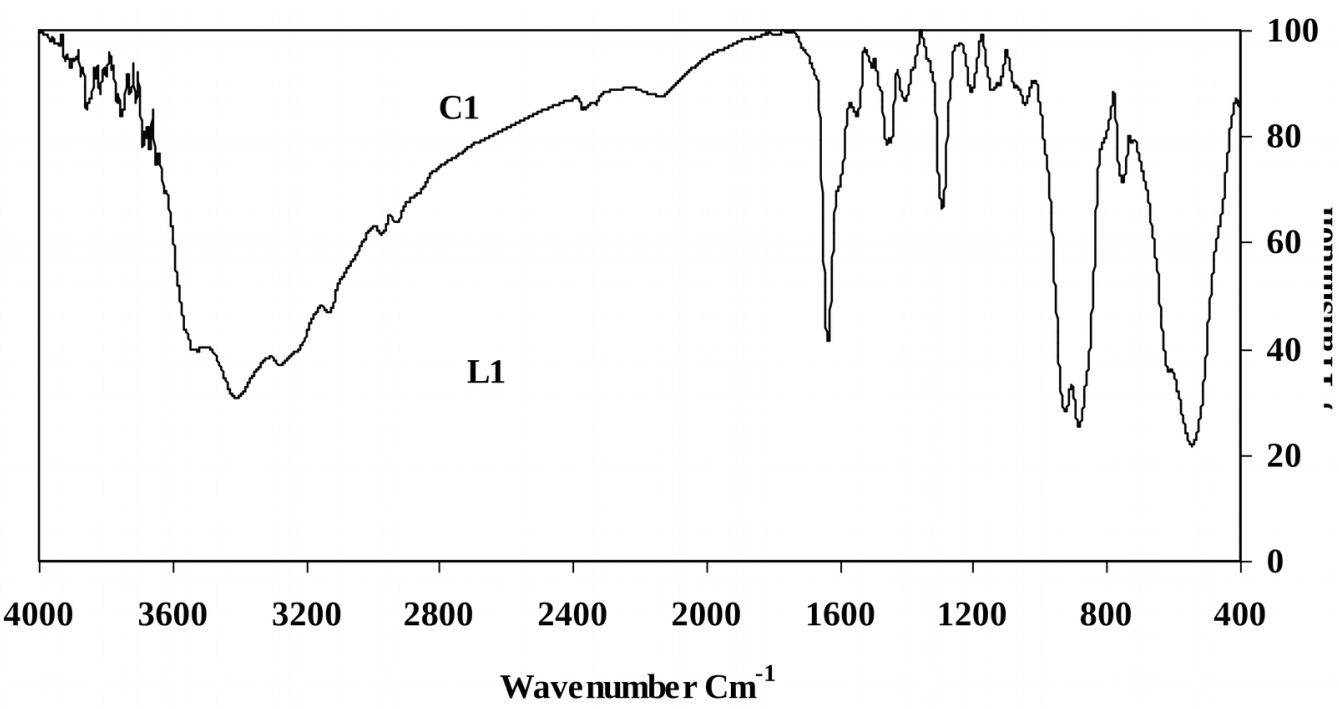

Fig. 2: infra-red spectra of ligand L1 (…) and complex C1 (-).

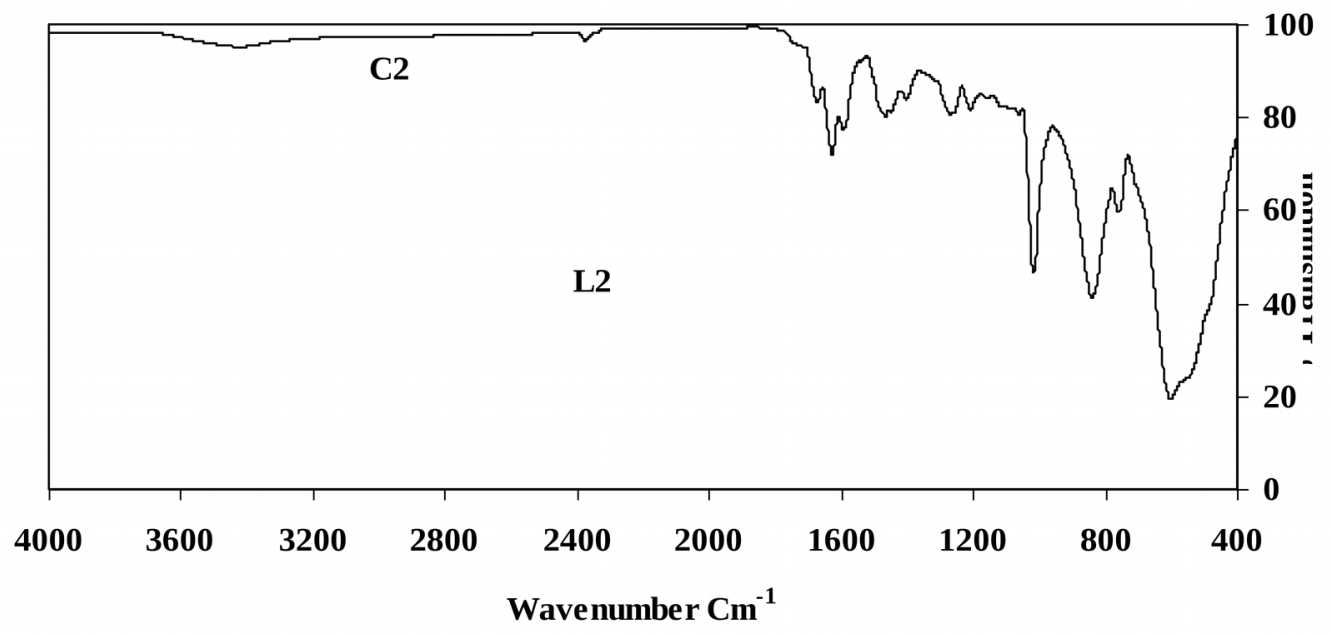

Fig. 3: infra-red spectra of ligand L2 (…) and complex C2 (-).
For

complex

$\mathrm{C} 2$ :

${ }^{1}$ HNMR

(DMSO-d $\mathrm{d}_{6}$ $\mathrm{ppm}): \delta=$ $3.32\left(\mathrm{CH}_{2}\right)$, 6.96-8.71

$(8 \mathrm{H}$ aromatic), 10.25 (aromatic, $\mathrm{H}-\mathrm{C}=\mathrm{N}$ ) and 10.90 $(\mathrm{H}-\mathrm{C}=\mathrm{N})$ $[18,19]$, Figures 5.

$\quad{ }^{13} \mathrm{CNM}$
$\mathrm{R} \quad(\mathrm{DMSO}-$
$\left.\mathrm{d}_{6}, \mathrm{ppm}\right): \delta$
$=\quad 52.96$
$\left(1 \mathrm{C}, \mathrm{CH}_{2}\right)$,
$121.54-$
160.46
$(10 \mathrm{C}$,
aromatic),
$162.75 \quad(1 \mathrm{C}$,
$\mathrm{C}=\mathrm{N}) \quad$ and
$163.00 \quad(1 \mathrm{C}$,
$\mathrm{C}=\mathrm{N})$,

Figures 5.

3.3.

Thermo gravimetric

For complex C1: 


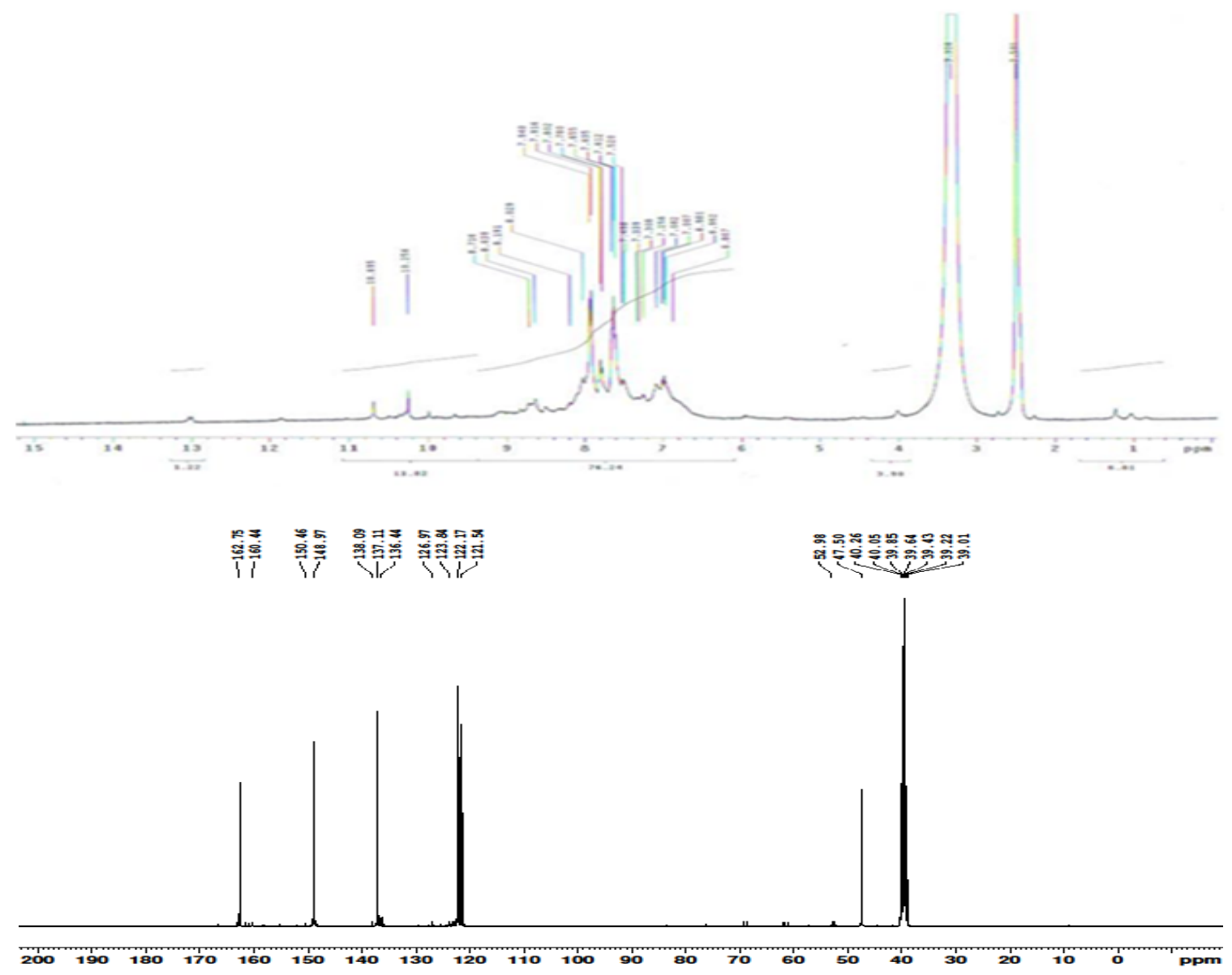

Fig. 5: ${ }^{1} \mathrm{H}-\mathrm{NMR}$ (upper) and ${ }^{13} \mathrm{C}-\mathrm{NMR}$ for complex $\mathrm{C} 2$ (lower).
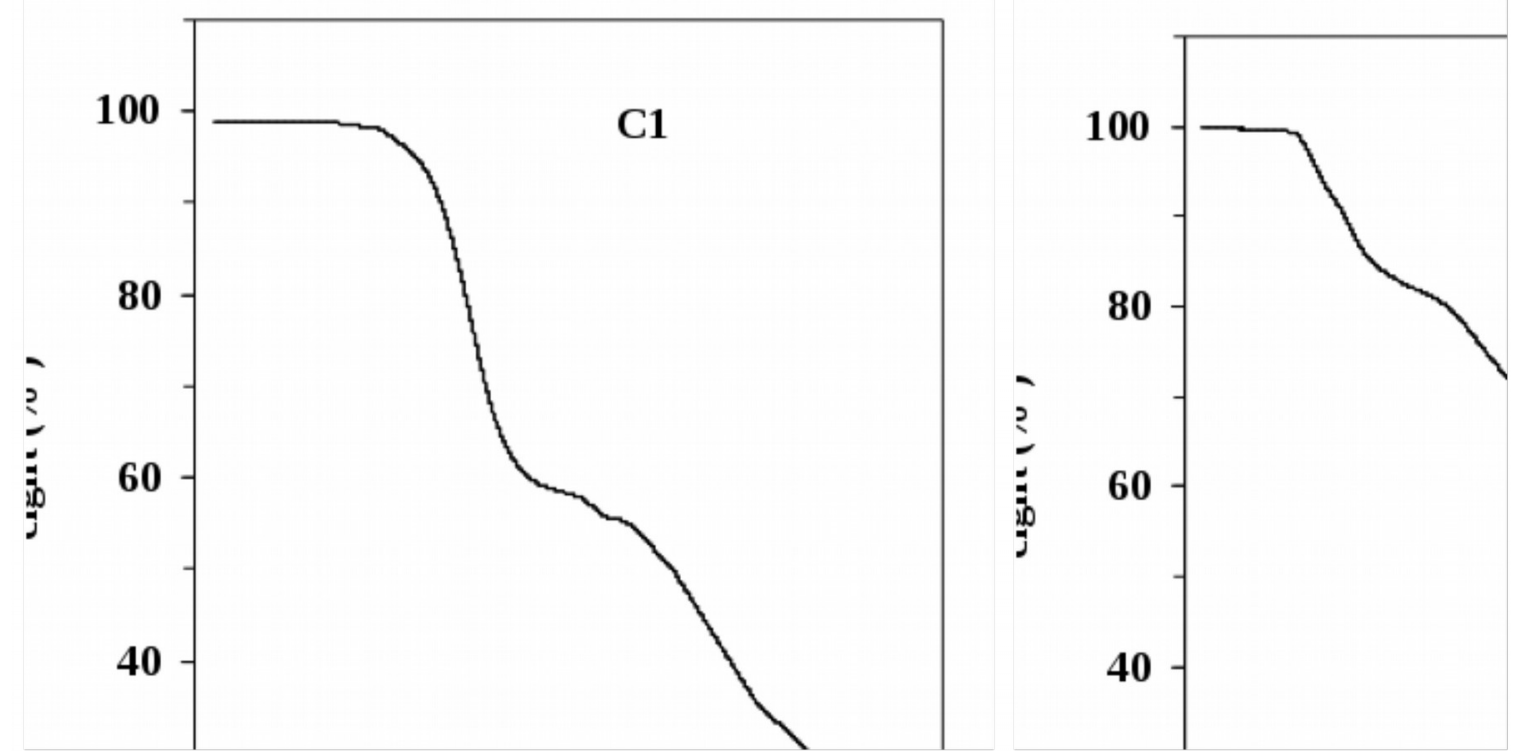

Fig. 6: TGA curve of complexes $\mathrm{C} 1$ and $\mathrm{C} 2$. 
DFT/B3LYP/LANL2DZ level of theory was used for the geometry optimization. Full geometry optimization was performed using B3LYP method with LANL2DZ as a basis set to generate the optimized structure of minimum energy for ligands and complexes.

\section{The Molecular modeling of ligand $\mathrm{L} 1$ and complex C1:}

Figure 7, shows the optimized structures of ligand (L1) and its complex (C1) as the minimum energy configurations. The vanadium atom is five-coordinate in a distorted trigonal bipyramidal geometry and the bond angles ranging from $76.93^{\circ}$ to $158.9^{\circ}$, Table 2 .

The atoms N1, O3, O4 and V are almost in one plane deviated by $9.26^{\circ}$. The axial bond angle of $\mathrm{O} 1-\mathrm{V}-\mathrm{N} 2,158.9^{\circ}$, is deviated from linearity due to coordination to vanadium. The bite angles N1-V-N2 and O1-V-N1 are 76.94 and $82.60^{\circ}$ lower than $90^{\circ}$ due to coordination. Moreover, the angles N1-C8-C9 and N2-C9-C8 were decreased upon complex formation, from 111.5 and 109.6 to 108.2 and 105.1, respectively.

The distance between donor atoms involved in coordination N1- - - -N2 is decreased upon complex formation from 2.963 $\AA$ (in free ligand) to $2.683 \AA$ (in the complex) but the distance between and N1- - - -O1 is slightly increased from $2.618 \AA$ (in free ligand) to $2.676 \AA$ (in the complex), which is probably due to the formation of hydrogen bonds between $\mathrm{N} 1$ and $\mathrm{HO} 1$ in L1, Figure 7. The two hydroxyl atoms in L1 are hydrogen bonded to the nitrogen atoms. The bond length of $\mathrm{V}-\mathrm{O} 1$ is $1.900 \AA$ longer than those of $\mathrm{V}=\mathrm{O} 3$ and $\mathrm{V}=\mathrm{O} 4$, which are 1.616 and $1.627 \AA$, respectively. The elongation of $\mathrm{N} 1=\mathrm{C} 7$ and $\mathrm{N} 2=\mathrm{C} 11$ bonds from 1.286 and $1.286 \AA$ in L1 to 1.319 and $1.305 \AA$ in $\mathrm{C} 1$ was due to coordination of $\mathrm{V}$ to both $\mathrm{N} 1$ and N2., Table 2.
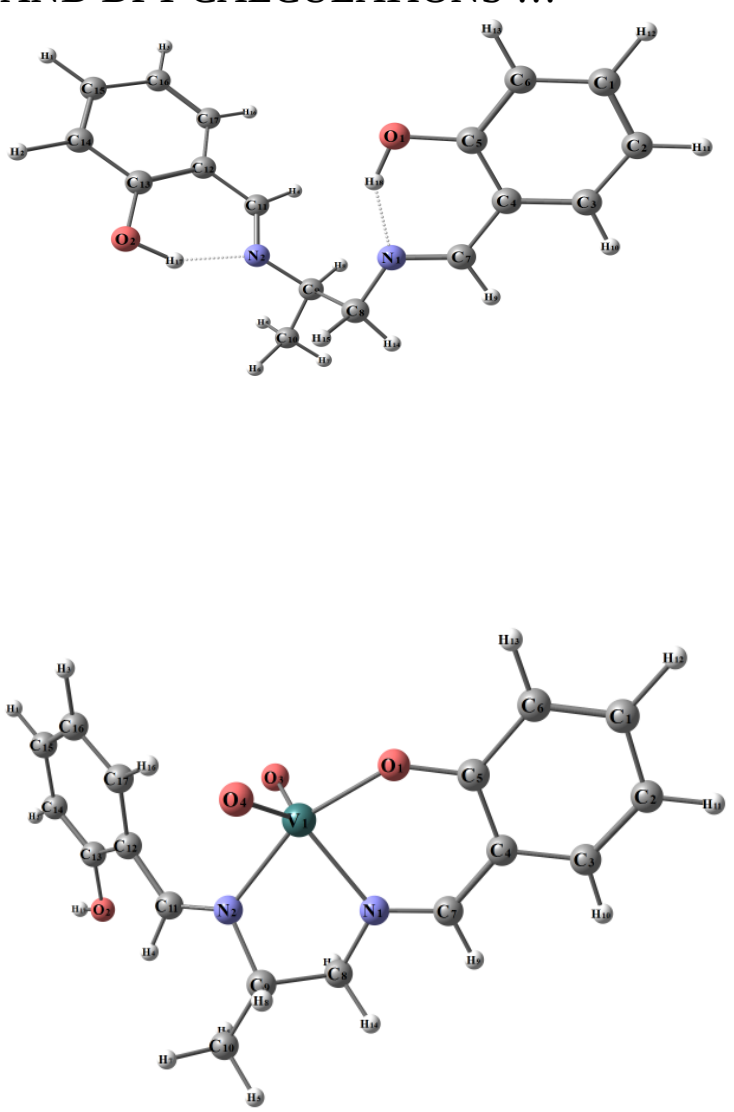

Fig.7: Optimized minimum energy structure of

L1 (upper) and its complex C1 (lower) calculated by density function B3LYP/LANL2DZ.

Table 2: Optimized Bond Lengths and angles of ligand L1 and complex C1

\begin{tabular}{|c|c|c|c|c|c|}
\hline \multirow{2}{*}{$\begin{array}{c}\text { Type of } \\
\text { bond }\end{array}$} & \multicolumn{2}{|c|}{ Bond length $(\AA)$} & \multirow{2}{*}{$\begin{array}{l}\text { Type of } \\
\text { Angle }\end{array}$} & \multicolumn{2}{|c|}{ Angle $\left(^{\circ}\right)$} \\
\hline & L1 & C1 & & L1 & C1 \\
\hline V-O1 & - & 1.900 & O4-V-N2 & - & 88.23 \\
\hline $\mathrm{V}=\mathrm{O} 3$ & - & 1.616 & O4-V-O3 & - & 110.9 \\
\hline $\mathrm{V}=\mathrm{O} 4$ & - & 1.627 & N1-V-O3 & - & 118.5 \\
\hline V-N1 & - & 2.145 & $\mathrm{~N} 1-\mathrm{V}-\mathrm{N} 2$ & - & 76.93 \\
\hline V-N2 & - & 2.168 & $\mathrm{~N} 2-\mathrm{V}-\mathrm{O} 3$ & - & 91.85 \\
\hline N1----N2 & 2.963 & 2.683 & O1-V-O3 & - & 102.4 \\
\hline N1----O1 & 2.618 & 2.676 & O1-V-O4 & - & 100.8 \\
\hline $\mathrm{N} 1=\mathrm{C} 7$ & 1.286 & 1.319 & O1-V-N1 & - & 82.60 \\
\hline \multirow[t]{4}{*}{$\mathrm{N} 2=\mathrm{C} 11$} & 1.286 & 1.305 & O1-V-N2 & - & 158.9 \\
\hline & & & O4-V-N1 & - & 128.5 \\
\hline & & & N1-C8-C9 & 111.5 & 108.2 \\
\hline & & & N2-C9-C8 & 109.6 & 105.1 \\
\hline
\end{tabular}

The Molecular Modeling of ligand L2 and complex C2: 
Figure 8, shows the optimized structures of ligand (L2) and its complex (C2) as the minimum energy configurations. The vanadium atom is five-coordinate in distorted trigonal bipyramidal geometry and the bond angles ranging from 74.58 to $157.3^{\circ}$, Table 4 . The atoms $\mathrm{N} 1, \mathrm{O} 2, \mathrm{O} 3$ and $\mathrm{V}$ are almost in one plane deviated by $11.85^{\circ}$. The axial bond angle of O1-V-N1, $157.3^{\circ}$, is deviated from linearity due to coordination to vanadium. The bite angles N1-V1-N2 and O1-V-N2 are 74.58 and $82.84^{\circ}$ lower than $90^{\circ}$ due to coordination. Moreover, the angles C12-N2-C13 and O1C10-C9 were decreased upon complex formation, from 118.2 and 124.1 to 116.6 and 121.0 , respectively.

The distance between donor atoms involved in coordination N1- - - - - N2 is decreased upon complex formation from $3.677 \AA$ (in free ligand) to $2.597 \AA$ (in the complex) and the distance between N1- - - -O1 and N2- - - - -O1 are also decreased from 7.099 and $4.219 \AA$ (in free ligand) to 3.952 and $2.685 \AA$ (in the complex), respectively, confirming the chelating to $\mathrm{V}$ atom. The bond length of $\mathrm{V}-\mathrm{O} 1$ is $1.895 \AA$ longer than those of $\mathrm{V}=\mathrm{O} 2$ and $\mathrm{V}=\mathrm{O} 3,1.619$ and $1.623 \AA$, respectively, Table 4 . The elongation of $\mathrm{N} 2=\mathrm{C} 12$ and $\mathrm{N} 2=\mathrm{C} 13$ bonds was also observed.
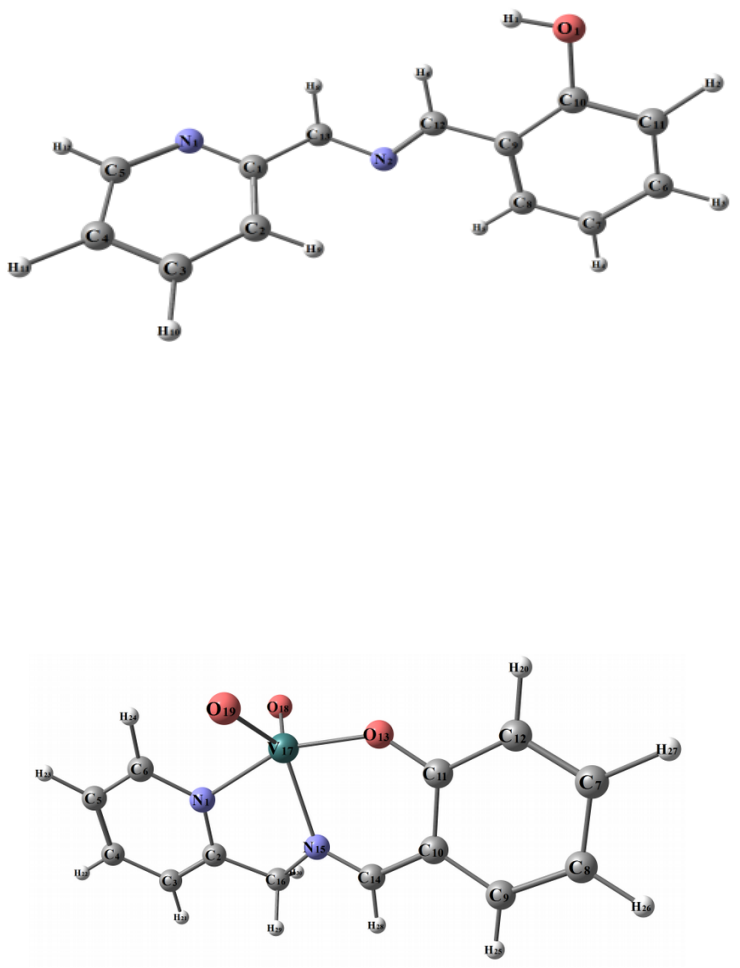

Fig. 8: Optimized minimum energy structure of L2 (upper) and its complex C2 (lower) calculated by density function B3LYP/LANL2DZ

Table 3: Optimized Bond Lengths and angles of ligand L2 and complex C2

\begin{tabular}{lcr|lrc}
\hline $\begin{array}{c}\text { Type of } \\
\text { bond }\end{array}$ & \multicolumn{2}{c|}{$\begin{array}{c}\text { Bond length }(\AA) \\
\text { L2 }\end{array}$} & C2 & Type of & \multicolumn{2}{c}{ Angle $\left(^{\circ}\right)$} \\
V-O1 & - & 1.895 & O1-V-O2 & - & 88.23 \\
V= O2 & - & 1.619 & O1-V-O3 & - & 110.9 \\
V= O3 & - & 1.623 & O1-V-N1 & - & 118.5 \\
V-N1 & - & 2.135 & O1-V-N2 & - & 76.93 \\
V-N2 & - & 2.151 & O2-V-O3 & - & 91.85 \\
N1- -- N2 & 3.677 & 2.597 & O2-V-N1 & - & 89.77 \\
O1-- -N2 & 4.219 & 2.685 & O2-V-N2 & - & 121.3 \\
N2=C12 & 1.275 & 1.320 & N1-V-O3 & - & 88.60 \\
N2-C13 & 1.448 & 1.483 & N1-V-N2 & - & 74.58 \\
& & & N2-V-O3 & - & 124.5 \\
& & & C12-N2-C13 & 118.2 & 116.6 \\
& & & O1-C10-C9 & 124.1 & 121.0 \\
\hline
\end{tabular}

The computed total energy, the highest occupied molecular orbital (HOMO) energies, the lowest unoccupied molecular orbital (LUMO) energies and the dipole moment for the ligands L1 and L2 and their complexes C1 
SYNTHESIS, CHARACTERIZATION AND DFT CALCULATIONS ...

and C2 were calculated, Table 4. The more negative values of total energy of the complexes than those of free ligands indicate the extra stability of the complexes than the free ligands. The polarities of the complexes are much larger than those of the free ligands, Table 4. The highest occupied molecular orbital (HOMO) energies, the lowest unoccupied molecular orbital (LUMO) energies of C1 and C2 are represented in Figures 9 and 10, respectively.

Table 4: Calculated energies of Ligands, L1 and L2, and complexes, Cland C2.

\begin{tabular}{llllll}
\hline & $\mathrm{E}^{\mathrm{a}}$ & $\mathrm{HOMO}^{\mathrm{b}}$ & $\mathrm{LUMO}^{\mathrm{c}}$ & $\Delta \mathrm{E}^{\mathrm{d}}$ & $\begin{array}{l}\text { Dipole } \\
\text { moment }\end{array}$ \\
\hline $\mathbf{L 1}$ & -918.635 & -0.2126 & -0.0511 & 0.1615 & 3.601 \\
$\mathbf{C 1}$ & -1139.801 & -0.2150 & -0.0799 & 0.1351 & 7.648 \\
\hline $\mathbf{L 2}$ & -687.335 & -0.2264 & -0.0504 & 0.1760 & 1.228 \\
$\mathbf{C 2}$ & -908.582 & -0.2206 & -0.0881 & 0.1325 & 9.6808 \\
\hline
\end{tabular}

${ }^{\mathrm{a}} \mathrm{E}$ : the total energy (a.u.). ${ }^{\mathrm{b}} \mathrm{HOMO}$ : highest occupied molecular orbital (eV).

'LUMO: lowest unoccupied molecular orbital $(\mathrm{eV})$.

${ }^{\mathrm{d}} \Delta \mathrm{E}: \mathrm{E}_{\text {LUмо- }} \mathrm{E}_{\text {номо }}(\mathrm{eV}) .{ }^{\mathrm{e}}$ dipole moment (Debye).

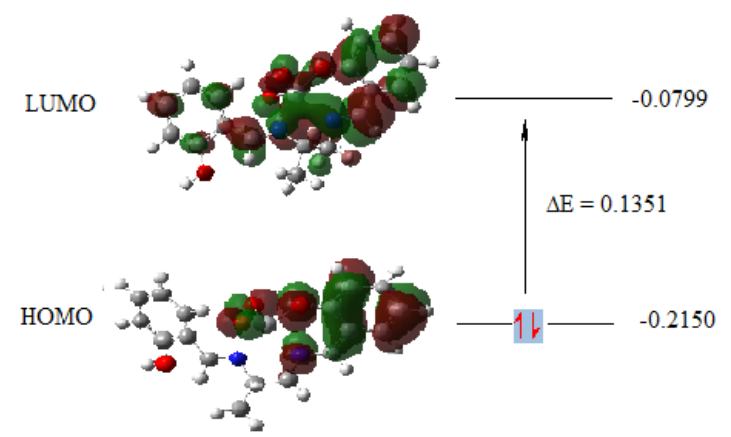

Fig. 9: The highest occupied molecular orbital (HOMO) energies and the lowest unoccupied molecular orbital (LUMO) energies in $\mathrm{eV}$ for $\mathrm{C} 1$.

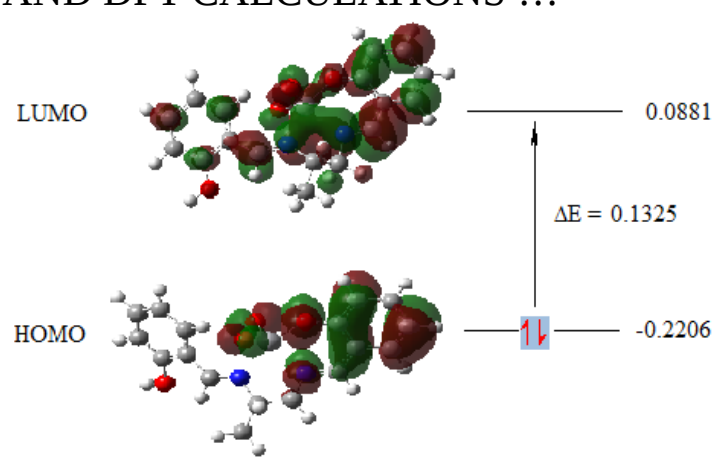

Fig. 10: The highest occupied molecular orbital (HOMO) energies and the lowest unoccupied molecular orbital (LUMO) energies in $\mathrm{eV}$ for $\mathrm{C} 2$.

\section{REFERENCES}

1. W. Plass; Coord. Chem. Rev., 255, 2378-2387 (2011).

2. Z. Cimerman, S. Miljanić, and N. Galić; Croatica Chemica acta., 73, 81-95 (2000).

3. A. Elmali, M. Kabak and Y. Elerman; J.Mol.Struct., 477, 151-158 (2000).

4. M. Nath and P.K. Saini; Dalton Trans., 40, 7077-7121 (2011).

5. S.P Chavan and R. Sivappa; Tetrahedron Lett. 45, 3941-3943 (2004).

6. P. Rathelot, N. Azas, H. El-Kashef, F. Delmas, C. Di Giorgio, P. Timon-David, J. Maldonado and P. Vanelle; Eur. J. Med.Chem., 37, 671-679 (2002).

7. R.P. Pawar, N.M. Andurkar and Y.B. Vibhute; $J$. Indian Chem. Soc., 76, 271-272 (1999).

8. A.A. Bekhit, H.T.Y. Fahmy, S.A.F. Rostom and A.M. Baraka; Eur. J. Med.Chem., 38, 27-36 (2003).

9. S. Cakir, M. Odabasoglu, E. Bicer and Z. Yazar; J. Mol. Struct., 918, 81-87 (2009).

10. D.R. Williams; Chem Rev., 72, 203-213 (1972).

11. S. N. Pandeya, D. Sriram, G. Nath, E. DeClercq, Eur. J. Pharm. Sci.,9, 25-31(1999).

12. G.A. Bain, D.X. West, J. Krejci, J. ValdesMartinez, S. Hernández-Ortega, R. A. oscano, Polyhedron. 16, 855-862 (1996).

13. W. Plass; Coord. Chem. Rev. 255 2378-2387 (2011).

14. D.C. Crans, J.J. Smee, E. Gaidamauskas and L. Yang; Chem. Rev., 104, 849-902 (2004).

15. W. Plass; Coord. Chem. Rev. 237, 205-212 (2003).

16. D. Rehder; Coord. Chem. Rev. 182, 297-322 (1999). 
17. D. Rehder; Angew. Chem. Int. Ed. Engl. 30, 148-167 (1991).

18. C.D. Beard, R. J. Barrie, J. Evans, W. Levason, G. Reid and M.D. Spicer, Eur. J. of Inor. Chem., 21, 4391-4398 (2006). Ir VO

19. C. Das, P. Adak, S. Mondal, R. Sekiya, R. Kuroda, S.I. Gorelsky and S.K. Chattopadhyay, Inorganic chemistry, 53, 11426-11437 (2014).

20. S. Cakir and E. Bcer, J. Chil. Chem. Soc., 55, 236-239 (2010).

21. M.A. Robb, J.R. Cheeseman, G. Scalmani, V. Barone, B. Mennucci, G.A. Petersson, H. Nakatsuji, M. Caricato, X. Li, H.P. Hratchian, A.F. Izmaylov, J. Bloino, G. Zheng, J.L. Sonnenberg, M. Hada, M. Ehara, K. Toyota, R. Fukuda, J. Hasegawa, M. Ishida, T. Nakajima, Y. Honda, O. Kitao, H. Nakai, T. Vreven, J.A. Montgomery, Jr., J.E. Peralta, F. Ogliaro, M. Bearpark, J.J. Heyd, E. Brothers, K.N. Kudin, V.N. Staroverov, R. Kobayashi, J. Normand, K. Raghavachari, A. Rendell, J.C. Burant, S.S. Iyengar, J. Tomasi, M. Cossi, N. Rega, J.M. Millam, M. Klene, J.E. Knox, J.B. Cross, V. Bakken, C. Adamo, J. Jaramillo, R. Gomperts, R.E. Stratmann, O. Yazyev, A.J. Austin, R. Cammi, C. Pomelli, J.W. Ochterski, R.L. Martin, K. Morokuma, V.G. Zakrzewski, G.A. Voth, P. Salvador, J.J. Dannenberg, S. Dapprich, A.D. Daniels, O. Farkas, J.B. Foresman, J.V. Ortiz, J. Cioslowski, D.J. Fox, Gaussian, Inc., Wallingford CT, (2009). 